DOI https://doi.org/10.36059/978-966-397-106-3/5-24

\title{
PEDAGOGICAL POTENTIAL OF MODERN UKRAINIAN ABECEDARY
}

\author{
Bessarab A. O.
}

\section{INTRODUCTION}

As early as in the beginning and in the middle of the XXth century there has emerged utopias (or rather dystopias) about the future society, in particular, about the people's lives without reading, such as: "Fahrenheit 451" by Ray Bradbury or, in part, "1984" by George Orwell. There are many essays on this subject ("Five Essays on Books and Readers" by Hermann Hesse, "Everlasting Man" by Gilbert Keith Chesterton, "Reading Lessons. Bibliophile Kamasutra" by Alexander Genis, etc.). Notably, the authors often are representatives of the countries where the level of reading and education of the population is high (according to official surveys). There is a paradox here: if a problem exists, initially only those who are less affected by this problem are able to understand it, as well as the need to solve it.

Modern realities indicate the loss by a book of its place in the system of values and the decline of the reading culture for a number of political, social and economic reasons, which leads to negative tendencies related to the level of education and spirituality of society. At the same time, reading has acquired a qualitatively new form on grounds of the spread of electronic books and online media.

The abecedary is one of the first books to introduce the child to reading, so its creation requires pedagogical talent and special skill of the text author, illustrator, designer, as well as careful selection of material for book production. The latest technologies and modern printing facilities open up new opportunities for educators to cultivate love of the book and create a culture of reading that needs academic comprehension.

\section{Various images of the Ukrainian abecedary}

The Ukrainian abecedary has a long history. Its first fragments were found in birch-bark manuscripts and "The Russian Primary Chronicle" which is a monument of Old Russian literature of the beginning of the 
XIIth century. Today, thanks to the latest technologies, access to the abecedaries text is provided on specialized web sites, in particular, on "Joyful Abecerady" web page (http://abetka.ukrlife.org/abetki.html)".

We will analyze in more details the abecedaries from Ukrainian publishing houses specializing in children's literature, such as: "A-baba-ha-la-ma-ha", "Ailes", "The Old Lion Publishing House", "KrystalBuk", "Mango", "Osnovy", "Pehas", "Pero", "Ranok", "Talant", "School", "Yunisoft", "Vivat" etc.

\section{Abecedary as book edition}

According to State Standards of Ukraine 3017-2015, a book edition is a block edition in a hardcover or binding ${ }^{2}$. It can be both a book in volume more than 48 pages, and a pamphlet in volume more than 4 , but less than 48 pages $^{3}$. Such editions can contain texts in poetical or prosaic form.

\section{Abecedary in verse}

Abecedary poetry is a specific poetical form, based on the sequence of letters in the alphabet, performing cognitive and educational functions. Usually, abecedaries for kids look like carton books. They are presented in a product range of many children's publishing houses. According to "Bokmal" editorship, the list of 25 children's books that had the greatest impact on all children's literature, is headed by Ivan Malkovych's "Abecedary" with illustrations by Kost Lavro: "In the beginning was the Word... And before the word, of course, were letters. So, we will start our collection of the most significant books of independent Ukraine from Ivan Malkovych's "Abecedary". The history of "A-ba-ba-ha-la-ma-ha" publishing house began exactly with it, and almost all little Ukrainians start their readers' journey exactly with it $^{4}$. This abecedary was awarded with the Grand Prix of "The Art of the Book" contest named after Ivan Fedorov, the first prize of the Forum of Ukrainian Publishers (1999), "The Best Children's Edition of 1999" title within the "Book of the Year" award, etc.

\footnotetext{
${ }^{1}$ Весела абетка. URL: http://abetka.ukrlife.org/abetki.html (access date: 07.05.2018).

${ }^{2}$ ДСТУ 3017:2015. Інформація та документація. Видання. Основні види. Терміни та визначення понять. Київ: Держстандарт України, 2016. С. 4.

${ }^{3}$ Там само. С. 18

4 Bokmal. 25 найзнаковіших дитячих книжок незалежної України. URL: https://bokmal.com.ua/books/25-dytiachykh-knyzhok-nezalezhnoji-ukrajiny/ (access date: 13.05.2018).
} 
K. Lavro's illustrative approach differs is notable for laconicity, simplicity of forms and exquisite color scheme. The ratio of the graphic part, the text blocks and the white background is harmoniously balanced in accordance with the requirements for typography for the youngest age category. Characters have a distinct ethnographic quality, which is especially valuable for the Ukrainian abecedary. It is worth noting the humorously rich detailing of the publication illustrations, which set the emotional mood and connection with the present. Abecedary skeleton letters of antique type have different colors on different pages, they are simple and legible for reading and easy memorization of a small child. The stylistics of these illustrations is substantially highlighted against the background of children's literature in general and abecedaries in particular.

\section{Fairy tale abecedary}

A fairy tale is a narrative folk-poetic or written-literary work on fictional events, fiction characters, sometimes with the participation of fantastic forces ${ }^{5}$. Writers use this genre because children like it. And the most active readers of fairy tales are children from three to ten or eleven years old. It was established that humor is especially attractive to readers, which is usually one of the main motives of story development in many fairy tales ${ }^{6}$. Neil Gaiman in his lecture on reading cites Albert Einstein, who once had been asked how to make our children smart: "If you want your children to be intelligent, read them fairy tales. If you want them to be more intelligent, read them more fairy tales" ". So a number of publishers decided to turn to this genre, preparing an abecedary:

- "Fairy Tale Abecedary" from "Pehas" publishing house (2013), the main character of which is the Wolf. The design solution for this abecedary is extremely low: heavy oversaturated illustrative part, dark coloured background, illuminated with blurred boxes under text blocks, random compositional placement of text blocks. The only positive moment is the animation of the letters: they have eyes, arms and legs, express emotions and perform certain actions. This is an

5 Словник української мови: в 11 т. Київ, 1979. URL: http://sum.in.ua/s/fotelj (access date: 30.04 .2018 ).

${ }^{6}$ Редакторская подготовка изданий: учебник / под общ. ред. С. Г. Антоновой. Москва: Изд-во МГУП, 2002. 468 с.

${ }^{7}$ Нил Гейман: Почему наше будущее зависит от библиотек, чтения и мечтаний. URL: http://www.kobu.kiev.ua (access date: 27.04.2018). 
effective graphical technique that provides the interaction of illustrations with the recipient;

- "Abecedary Fairy Tale" from "Ailes" publishing house (2015) along the "Teaching Kid" series with verses by Oleh Maiboroda, illustrations by "Almaz" design group;

- "Abecedary in Fairy Tales" by Oleh Maiboroda from Kharkov "Yunisoft" publishing house (2017), along "Tomorrow to School" series. This publication contains short texts-tales and funny illustrations. It is aimed at developing of reading skills, intelligible pronunciation of complex sounds and enriching the child's vocabulary with a large number of words beginning with a certain letter.

Illustrator Olesia Maherovska clearly caught the target audience of such an abecedary. This book is intended for children who already had been educated to read and are ready for school. It is rather interesting stories about letters, which have to reintroduce themselves and motivate the future pupils to read. That is why the textual part dominates the graphic one, because the attention of the young reader is shifted to the content of fairy tales. Skeleton letters are hiding in illustrative stories behind the figures of the leading characters of fairy tales, and as a result the letters can be seen only partially and it is difficult to read them clearly. This happened, for example, with the letters $\Pi, \boldsymbol{\Phi}$, Ц. It can be considered as a disadvantage, or as an interactive quest in the search for a letter.

Some fairy tales dedicated to the corresponding letter begin with a new page, and some are not. We do not see justified explanations of this state of things.

Abecedaries in verses and fairy tale abecedaries can be conventionally included in the group of children's books, where the ratio between the text and the illustrative collection is fifty-fifty, and it varies depending on the purpose of the book (informative, entertainment, etc.), the target audience (age of recipients - preschool, junior school), thematic specialization (about animals, cars, toys, etc.). The illustrative part should not only explain the text but also continue the verse or fairy tale, reveal the subtext, inspire to think and fantasize. From the designer's point of view, the basic requirement is the correct direction of graphic accents and composite tools for the assembly and text elements composition in order to avoid diversity of colours and monotony. 


\section{Abecedary with reproductions of art pieces}

A special place among the analyzed editions has Anna Kopilova's "Abecedary" from "Osnovy" publishing house (2016), illustrated with masterpieces of painting, graphics, sculpture and decorative art from the collection of Bohdan and Varvara Khanenko National Museum of Arts in Kyiv. The idea of such a solution is not new, such an abecedary has, for example, the Russian Hermitage. This idea comes from museum workers in order to attract children and their parents to art. Looks like an advertising tool, but relevant and cognitive.

Each letter in the abecedary is illustrated by one or several works from the museum. For example, the $\mathbf{B}$ letter is represented by the "взуття" (shoes) word and illustrated by the work of the famous Pieter Brueghel II, "The Funny Company". The titles of paintings and names of authors can be found only in the general list of used works, while on the letters' pages the illustrations are not signed, although it would be appropriate, because the publication presents for study not only letters, but also works of art. It is difficult to determine the age group of such an abecedary, the publication rather has the target audience, interested in art, music, theater.

\section{Jigsaw puzzle abecedary}

This refers to book editions that contain puzzle pages. Neither the Ukrainian language dictionary defines the "puzzle" word, nor the publishing standards. However, puzzles are widely represented in the product range of publishing houses, they are strongly recommended by child psychologists to develop speech. The most corresponding term to characterize a publication with jigsaw puzzles is a "toy book" - "the publication of the unique structural form, intended for the mental and aesthetic development of children of preschool and junior school age" 8 . The jigsaw puzzle is a puzzle game that looks like a mosaic that should be composed of a multitude of fragments of a picture of different shapes. It is one of the most affordable toys that develop logical thinking, attention, memory, imagination"9.

For example, "Alphabet. Great Book of Puzzles" with verses by Hennadii Malamed from "Ranok" publishing house (2013); "Abecedary"

8 ДСТУ 3017:2015. Інформація та документація. видання. Основні види. Терміни та визначення понять. Київ : Держстандарт України, 2016. С. 7. 30.04.2018).

Пазл. Вікіпедія. URL: https://uk.wikipedia.org/wiki/Пазл (access date: 
and "Fairy-Tale Abecedary" with verses by N. Horborukova from the "Septima" publishing house (2016); "First Abecedary", "Fairy-Tale Abecedary", "Live Abecedary" from "Krystal Buk" publishing house (2017) (illustrations by Olena Zarbi-Halchuk, the author of verses is not specified); "Abecedary" and "Fluffy Abecedary" with verses by Yuliia Turchyna and Oksana Zhlobynska, artist O. Yu. Stanilevych from "Pehas" publishing house (2017).

Ukrainian "Zirka" company has developed the "Ukrainian Abecedary" learning game in size of $195 \times 280$, which consists of 36 jigsaw puzzles with images of letters, which should be inserted into the appropriate cells.

"Fluffy Abecedary" of "Pehas" publishing house is represented by animalistic stylized motifs. The book page spread consists of two pages: one with letters, verses and small illustrations of birds and animals, and the other is jigsaw puzzles, from which the plot contexture is composed. It is worth noting the overload of the graphic part of the book: it is a coloured ornamented background, a large number of colours, frames, decorative elements (asterisks, dashes, etc.), pseudo-volumes of letters. All this hinders the legibility of the text and the ease of information perception.

"First Abecedary" of "Krystal Buk" publishing house in format of $23 \times 15$. Attempts to find room on a page for letters, verses, illustrations to them, and also place on the other page pictures with puzzles led to small illegible elements, where the eye can not stop and highlight the main thing. A child will be interested rather in colored illustrations of puzzles than letters. The graphical solution of letters is completely unsuccessful, they all have shadows, it does not separate the letter from the background, but creates the impression of dirt and cheap effects.

The main function of jigsaw puzzles abecedaries is interactivity; modern children are ready to consume it in all forms and in large numbers. That is why publishers, often saving on design and performance time, focusing on the game qualities of jigsaw puzzles, produce a book product of medium quality.

\section{Toy blocks abecedary}

Another one variant of the publishing embodiment of a toy book is the toy blocks abecedaries. "Torsynh" publishing house developed the following abecedary: it can be folded in the form of toy blocks and a 
child can consistently study the words on each side of the cube, as well as spread it out as a poster, or cut it into cards.

By the structure, the toy block book is a volumetric spatial object, therefore, together with the requirements for the children's book, it is necessary to take into account the peculiarities inherent in the design of the packaging and the volume advertising structures. The design of such blocks is complicated by the fact that elements of the text and images develop in three coordinate directions, which should be interrelated in compositional and stylistic solutions. In the toy blocks book from "Torsynh", there is no such relation, the volume of the block is leveled, the sign and graphic series is monotonous and uninteresting.

Russian "Clever" publishing house also offers toy blocks books, but it refers to small book editions with rounded edges that should be thumbed, not folded or cut. According to the information provided on the the publishing house website, "The book of Marina Druzhinina "My First Abecedary in Verse" is four funny toy block books in one box! ... Blocks are perfect for small hands, they are comfortable and safe, they can be used as building bricks for a tower or as rattles. Each letter corresponds to a funny verse and an interesting picture on which the kid will find not one but three or four words begin with the suitable letter! Moreover, with this book, the kid will learn many new animals, objects and words" $"$. As we can see, the "toy block book" is used to refer to editions, different in material construction. This is due to the fact that publishing standards are behind the designers imagination. It is worth noting that the book is made of super-tough check and really resembles a cube by the structure. It has unique laconic illustrations, and a wellchosen color scheme.

Stencil abecedary

"Ranok" publishing house produced "Fiksi-Stencil. Abecedary" publication with verses by Iryna Sonechko and "Stencil. Abecedary" with verses by Hennadii Malamed (2012). Swinging sheets are fastened with a spring to allow the child to conveniently outline letters and pictures, draw inside the stencil and write the words. Graphically and technically, the complexity of the stencil is in the form and size of the letter cutout. The cutout size should allow to shade easily inside it, while the indentions between the skeleton elements should be taken into

${ }^{10} 4$ книжки-кубика. Моя первая азбука в стихах. URL: https://www.clevermedia.ru/CleverProducts/Books/book_16662/ (access date: 30.04.2018). 
account, so a child would not tear the cardboard. This is considered in "Fiksi" series, and a sign set successfully submits graphic elements. It is worth emphasizing the interactivity of the stencil, aimed at development of the graphic abilities and skills, as well as visual thinking of a child.

Colouring abecedary, abecedary with stickers

"Abecedary. Reusable Stickers" edition with stickers for learning the letters (2017) is offered by "Krystal Buk" publishing house. This edition looks like a page spread of glossy cardboard and an inset with the stickers. It's difficult to speak on the book architectonics, because it's just separate elements, letters and relevant characters, that a child should stick in the right section. The main and positive element of this edition is interactivity.

The colouring abecedary of Mariia Smuhasta and Yuliia Smal from "Folio" publishing house (2014) also contains stickers. An example of classic coloring book, in which it is necessary to colour a letter and an illustration to it. By doing this, a child develops fine motor skills and visual-motor coordination, which provides the basis for further writing and good calligraphy.

It is also worth mentioning the Ukrainian abecedary with stickers, with verses, tautograms from the "Torsinh Plus" publishing house from the "Learning by Playing" series. The size of the book meets the requirements of the age category, the structure of this book is composed according to the scheme of the classical abecedary, even the division of the page spreads into four letters is saved. This is an example of a wellexecuted producing of the book: the illustrative set and graphemes are proportionally correlated, the font unit with verses is easy to read, it is quickly memorized, blank sections for stickers create the game mood, functioning as a break in the study of letters. Well-placed content and illustrative accents help to develop the intellectual and manual-practical abilities of a child.

In 2017, "Krystal Buk" publishing house presented reusable water colouring books: "First Abecedary" and "Live Abecedary", which only need water and a brush for painting. The effect of transparency of paper under the influence of water is used to create the "reusability" quality. If you damp the top layer of the page spread, it becomes transparent and adheres to the illustration below it, thus the picture from the bottom layer becomes visible. This variant, in our opinion, is more suitable to study physics than alphabet. The illustration set is overloaded, and 
proceeding from the style it's difficult to define the intended age category.

\section{Music abecedary}

In 2013, "Nederytsia S. S." publishing house released "First Musical Abecedary" within "Aesthetic Education of Future Genius" book series, which contains coloring book and $\mathrm{CD}$, which allows a child to listen, sing, dance and have fun learning the alphabet. Each letter is accompanied by a musical composition, which interestingly combines classical music, sounds of nature and voices of animals, along with verses by Svitlana Polischuk. The colouring part duplicates pictures from the book.

\section{Abecedary with augmented reality}

A novelty in the publishing market is publications, created with the help of AR-technologies, or augmented reality technologies. In appearance, a book with AR elements is the same as any print edition, but with the help of a camera, screen and corresponding software, it becomes a multimedia object with additional visual content. The software can be downloaded for free from the publisher's site ${ }^{11}$.

In the Ukrainian market AR-technologies are represented in the category of children's books by "Devar" publishing house in the form of coloring books, live books, live abecedaries, etc. All editions are available in quick view mode and are categorized as "Live Fairy Tales", "Live Coloring Books", "Finish the Drawing and Animate", "Live Abecedary", "Drive", "World of Animals", "Live Pictures", "Live Notebooks" $"$. Within this research we are interested in the abecedary. However, the product range of this publishing house contains is the abecedary of only English and Russian languages.

In 2018, "FastAR kids" publishing house introduced, according to them, the first "Live Abecedary" in Ukraine, in which each page "become alive". This is a unique combination of IT technologies with the classic book publishing ${ }^{13}$.

Abecedary on cards

According to State Standards of Ukraine 3017-2015, the loose-leaf encased set is a collection of editions collected to a folder, a case, a

11 Devar: официальный сайт. URL: http://devar.ru/o_kompanii (access date: 30.03.2018)

${ }_{12}^{12}$ Там само.

13 Жива абетка. URL: https://www.yakaboo.ua/zhiva-abetka-1641098.html (access date: 30.04 .2018$)$. 
parcel or enclosed in a cover ${ }^{14}$. A number of publishing houses offers abecedaries on cards, for example:

"Chytaika" abecedary in cardboard cards from "School" publishing house contains 40 pages (of $105 \times 105 \times 75$ format), author Vasyl Fediienko, 2018 As it stated on the publishing house website, "the proposed set of cards contains the letters of the Ukrainian alphabet, words and colorful images of objects. Using it a child can learn to compose words during the game. And beautiful drawings will help children to memorize and learn new knowledge in the best way. A selection of words, font, size and thickness of cards are methodically optimal $^{15}$. Moreover, the description adds the advantages of such a set of letters: "the possibility to compose syllables and words; the possibility to determine the place of the letter in the word; detailed instruction for parents inside; great drawings by Yevheniia Zhytnyk; methodically optimal selection of words, font, size and thickness of cards; the highest printing quality at an affordable price; meets state sanitary norms" ${ }^{\prime 16}$. The drawings are really nice, though they are bromidic.

In 2018, the similar set "Abecedary. Letters on Cards" of 30 cardboard cards (of $105 \times 110 \times 55$ format) is offered by "Publisher FO-P Zalohin S. O." publishing house.

Regarding this set, it should be noted that one side of cards has clearly printed letters, and the other side has letters with a smaller size, just one image of an object or an animal whose names begin with the corresponding letter, and the designation words, without division into syllables, without emphasis, which is a disadvantage of this edition. And letters И, Й, Ш, Щ are not provided with any image or word. This set from "Publisher FO-P Zalohin S. O." publishing house loses to a set from "School" publishing house.

"Abecedary" set of 33 cards of $110 \times 105$ size is also offered by "Sova" publishing house. The cards have a letter printed in red, the word that begins with it, and the corresponding image (usually it is an animal and edible fruit of a plant). There is also no division into syllables, no emphasis is placed on, so it is the lack of this edition. The illustrated series consists of photographs, which is quite rare feature in publications

14 ДСТУ 3017:2015. Інформація та документація. Видання. Основні види. Терміни та визначення понять. Київ: Держстандарт України, 2016. 38 с.

15 Видавництво "Школа". URL: https://schoolbook.com.ua/ru/books/abetkachitayka/ (accessed date: 30.04.2018).

${ }_{16}$ Там само. 
for children. After all, the simplification and generalization that occurs in the illustration process is not inherent to the photograph. But it should be noted that in this series of cards, the photograph is harmoniously fitted. The disadvantage of graphic design are the colored frames that should have set the gaming mood to the text and illustrative blocks in the structure of the cards, but, on the contrary, had resulted in monotony.

In 2012, "Rozumna Dytyna" publishing house prepared "Magic Box" (illustrator Arsen Dzhanikian), which is a set of thick cardboard cards for studying the alphabet. Each of them has a letter and two words with the corresponding images. The words are divided into syllables and the corresponding letters are highlighted in red, however, emphasis is not given. Famous illustrator Arsen Dzhanikian, who started with clay animation, stuck with the imagery and plasticity of clay in emotional characters that illustrated all the letters. The graphemes dimensions, color, and their legibility are consistent with all designer requirements for a children's book.

Another one variant is "Abecedary on Magnets" toy book, which is a universal guide for the development of the child. Cards in the form of jigsaw puzzles on magnets can become both game and educational material. Ease of use will allow to arrange lessons to a professional teacher, a starting kindergartner, and young parents. In 2010, such a set of 70x100/4 ( 330x310) format was offered by "Arhument-Prynt" publishing house.

\section{Poster abecedary}

According to State Standards of Ukraine 3017-2015, a poster is a publication in the form of one or several sheets of printed material of the prescribed format, printed on one or both sides of the sheet, intended for exhibition. A number of companies offer interactive poster abecedaries $^{17}$.

Talking abecedaries allow you to teach a child not only to speak, but also to learn the correct names of letters, as well as numbers, calculation, and even simple mathematical operations. To start your child's preparation for school you can buy a musical abecedary and go through all the tasks together. Children's posters abecedaries can voice letters, tell verses in which various letters are presented, as well as voice some words that are drawn on a button and begin with a

17 ДСТУ 3017:2015. Інформація та документація. видання. Основні види. Терміни та визначення понять. Київ: Держстандарт України, 2016. 38 с. 
specific letter. Children have very well developed imaginative thinking, which, thus, will help them to memorize the entire alphabet more quickly.

"Little ABC-book" interactive poster from JOY TOY will help a child to get acquainted with the Ukrainian alphabet while playing. This abecedary is an excellent solution for an independent kid's game and preparation for school. The kid can also learn how to count, will learn colors, and rapid saying. After the learning the kid can listen to songs or play. The abecedary can be hung on the wall or placed on a table, it is easy to fold, it always can be taken along. The interactive poster has a waterproof surface, touch buttons, volume control, auto shut-off to save battery ${ }^{18}$.

The own experience of using such a poster indicates that it requires a smooth solid surface, otherwise it will not respond adequately to the press and will voice the names of the letters incorrectly. And if you want to take it somewhere along, as the manufacturer suggests, do not bend or twist it.

\section{Abecedary as a mobile game}

As stated on zaxid.net website, in Lviv, the first Ukrainian interactive mobile game for children of 2-5 years old "Mousekin Abecedary" was developed, which is distributed free of charge. It is available for tablets, smartphones and personal computers, and is also suitable for children and parents with hearing disabilities ${ }^{19}$. The music design of "Mousekin Abecedary" was created free of charge by composer Volodymyr Yakymets, vocalist and artistic director of "Pikkardiiska Tertsiia". The abecedary was voiced by the actress of "I liudy, i lialky" Lviv theater Nadiia Krat. In general, on creation of the interactive abecedary a team of 20 people have worked: artist Yuliia Kutsmida; authors Halyna Andrusiv, Roman Hrypa, Mar'ian Hulchevskyi, Dmytro Doskoch, Olesia Diachyshyn, Yurii Diachyshyn, Liliia Liashok, Andrii Noha, Ihor Pavliuk, Roman Teslia, Vitalii Sheptytskyi; composer Volodymyr Yakymets; voice of the Mousekin by Nadiia Krat; audio effects by Yurii Okonchenko; sound by Bohdan

${ }^{18}$ Інтерактивні абетки, плакати. URL: https://toys.com.ua/ua/govoryaschie-azbuki (access date: 30.04 .2018$)$.

19 Зубрицька Н. У Львові створили першу українську інтерактивну абетку. URL: https://zaxid.net/u_lvovi_stvorili_pershu_ukrayinsku_interaktivnu_abetku_n1263554 (access date: 28.04.2018). 
Stefura; SEO Pavlo Lysyi; testers Khrystyna Hrypa, Vira Prots, Maks Diachyshyn $^{20}$.

The Mousekin, which is the main character of the abecedary, was named Krut after a mouse from the famous Ukrainian fairy tale about a cockerel and two mice. Stylistics of the graphic series is typical for computer games, but corrected for two decades. Such games were popular in the late 1990s - at the beginning of 2000. Characters and the graphical solution of "Mousekin Abecedary" environment have a black frame contour, unpleasant for perception. The color scheme is "lurid", color contrast interferes with perception and makes eyes tired. Other examples of modern animation, in particular such Ukrainian alphabets as "Talking Abecedary", "Bukvohraika", "ABC Color Abecedary for Children", show a higher level of graphic series.

An interesting invention of the companies producing toys for kids are interactive soft toys-abecedaries, made in the form of a teddy bear or other animal. On the toy animal belly is the entire alphabet, and on the paws various figures are. However, this is an object of study of specialists in other branches.

\section{Recommendations on abecedary composing and design}

Analysis of the abecedaries from the Ukrainian publishing houses "A-ba-ba-ha-la-ma-ha", "Ailes", "Veselka", "The Old Lion Publishing House", "Publisher FO-P Zalohin S. O.", "Krystal-Buk", "Mamino", "Mango", "Pehas", "Pero", "Ranok", "Talant", "School", "Yunisoft", "Vivat" shows that during preparation of this kind of editions for children it is worth pay attention to the following:

1. Compliance with the declared genre - an abecedary. According to our research, publishers, approving the title of the publication, do not take into account the differences between the words abecedary, $A B C$ book, the first reading book, etc. So, in our opinion, "Abecedary in Fairy Tales" by Oleh Maiboroda from Kharkiv "Yunisoft" publishing house, despite all its advantages, is not actually an abecedary, it is not even an $\mathrm{ABC}$ book, because the words are given without division into syllables, without emphases. A similar situation with "Cossack Abecedary" (compiled by O. Yaremiichuk) from "Veselka", which contains short stories and artistic works about the most significant events and the most

${ }^{20}$ Мишеняткова абетка. Дитяча інтерактивна гра. URL: http://www.mousealphabet.com/ua/ (access date: 30.04.2018). 
prominent heroes of the Cossack age alphabetically. Another example of the reading book, and not the abecedary actually is "Funny Abecedary" by Liubov Yakovenko from the "Yunisoft" publishing house, published in 2016.

2. Correspondence of the title with the publication content. For example, it is not always clear what useful is in the "Useful Abecedary" with the verses by Iryna Sonechko, and what funny is in the "Funny Letters" with the verses by Rinat Kurmashev from the "Ranok" publishing house. In our opinion, the use of Coca-Cola can hardly be called as useful, and the destruction of a built house - as funny action.

3. Representation of all letters in the alphabet, even if there are no words in the Ukrainian language that begin with them. So, "Funny Abecedary" by Liubov Yakovenko from "Yunisoft" publishing house contains the story for each letter in 1-2 pages, in which all words begin with the same letter. At the end of the texts there are notes explaining unfamiliar words. However, the $\mathbf{И}$ letter is omitted in the book, because Ukrainian language has no words that start with it. In our opinion, it would be worth at least to submit the letter itself and images for the words that contain it, because the publication title has the "abecedary" word, which means "a set of letters established in writing of any language and placed in a certain fixed order" ${ }^{21}$.

An interesting way out with the lack of words start with the corresponding letter was found in "Ranok" publishing house: in 2018, within "Interesting Abecedaries" series they published the "Abecedary of Riddles", "What Letters Look Like", "Useful Abecedary" with verses by Iryna Sonechko and "Funny Letters" with verses by Rinat Kurmashev in translation by L. Opanasenko. For example, even if there is no word starting with $\mathbf{b}$, in "What Letters Look Like" abecedary it was compared to a scoop, and not left overlooked. In "Abecedary about Animals and Cubs" ("Vivat", 2017) by Volodymyr Verkhoven, the letter $\mathbf{b}$ is provided with verses, the words of which contain it.

4. Careful selection of lexical material. The words mentioned in the editions for children should be familiar to the readers and refer, first of all, objects existing in the modern world. The most commonly used group of lexis designate plants, animals, food and transport, which can be reflected in the title of the publication: Volodymyr Verkhoven,

${ }^{21}$ Абетка. Словник української мови: в 11 т. Київ, 1970. URL: http://sum.in.ua/s/abetka (access date: 27.05.2018). 
"Flower Abecedary" ("Talant", 2014); Volodymyr Verkhoven, "Abecedary about Animals and Cubs" ("Vivat", 2017); Iryna Sonechko, "Tasty Abecedary" ("Ranok", 2014); Hennadii Malamed, "Abecedary of Cars" ("Ranok", 2015); Rinat Kurmashev, "Abecedary of Motor-Cars" ("Ranok", 2017). At the same time, relying on familiar lexis, the publication should help to enrich the vocabulary of readers.

"Abecedary of Colorful Exclamations" by Kateryna Perkonos with illustrations by Alona Yastremska from Kyiv "Mamino" publishing house (2018), which introduces letters, colors and emotions, differs from issues, popular in the market of publishing produts. The annotation of the publication states: "On the pages of the book there are 33 colorful characters, and everyone exclaims something: one is happy, another is surprised, the third is angry ... Each has its own temper. What colorful are they! But what strange names the colors have? Images will tell small readers where these names come from and how to invent their own. And the fact that the book is based on the "mix \& match" principle, then there are actually a lot of funny and oddish creatures here: parts of the pages can be combined with each other and in any way and a child can create almost 36,000 different combinations. Education has never been so bright and fun" 22 .

Abecedaries enrich the vocabulary of kids, introducing them to synonymous rows. For example, in "My First Abecedaryl" from "Pehas" publishing house the word "віслючок" (colt) is used, and in "First Abecedary" from "Krystal-Buk" publishing house the word "осля" (little donkey) is used, both of which are in "Ukrainian Language Dictionary".

5. Compliance with the norms of contemporary Ukrainian literary language. In general, we must note the high level of production of analyzed publications. However, we nevertheless found some language mistakes, for example, the book of 2013 from "Pero" publishing house is titled as "Розвиваюча абетка" ("Developing Abecedary"), while it would be correct to title it as "Розвивальна абетка" ("Developmental Abecedary"). The edition contains 160 pages of verses and riddles, games and interesting tasks that can be performed right away on the pages, but there are doubts: what will the book with a mistake on the cover teach?

22 Абетка Барвистих Вигуків. MAMINO: сайт. URL: http://maminobooks.com.ua/ detskie-knigi/Abetka-Barvystyh-Vygukiv (access date: 27.05.2018). 
In "Fairy Tale Abecedary" from "Ailes" publishing house (2015) with verses by Oleh Maiboroda, in one case, there is an error in the use of the vocative case of the "баран" ("ram") word, whereas further in the text it used correctly.

A similar situation with another edition of this publisher - in "Abecedary" (2016) with verses by O. Zolochevska, where there is also a mistake in the use of the vocative case, further in the text it used correctly.

In general, in production a publication for children, there is a need in careful selection of understandable words. For example, in "Abecedary for Kids about Animals and Cubs" from "Vivat" publishing house the "фотель" dialect word is used, which means "an armchair" 23. For the sake of justice, we must note that this becomes clear from the illustration accompanying the verse.

6. Marking emphasis in words. From the analyzed abecedaries, the emphasis is marked only in "Abecedary" by Oksana Krotiuk from "The Old Lion Publishing House". In "Abecedary" from "A-ba-ba-ha-la-maha" emphasis is only in a few words. This is related to a note about compliance with the selected metre. For example, in "Funny Abecedary" with the verses by Rinat Kurmashev from "Ranok" publishing house there is a violation of the rhythm, which may cause incorrect memorization of the emphasis in the "ягідки" ("berries") word.

7. Highlighting of the corresponding letter in a different color, as in the mentioned edition of "The Old Lion Publishig House", "Abecedary" by "A-ba-ba-ha-la-ma-ha", "Abecedary for Kids about Animals and Cubs" by "Vivat" publishing house, or a font design, as in "Fairy Tale Abecedary) of "Ailes" publishing house.

8. Careful selection of illustrative material considering educational potential and national traditions. In general, a showpiece in this aspect is "Abecedary" from "A-ba-ba-ha-la-ma-ha", which is composed on the basis of Ukrainian folklore and illustrated correspondingly.

Another one example is "Abecedary" by O. Krotiuk from "The Old Lion Publishing House" (2014), where, for example, the I letter is provided by a verse, by which a child joins the traditions of the nation. The "фіранка" (curtain) word denotes a piece of cloth or tulle, covering

${ }^{23}$ Фотелі. Словник украӥнської мови: в 11 т. Київ, 1979. URL: http://sum.in.ua/s/fotelj (access date: 27.05.2018). 
a window, a door, etc. ${ }^{24}$. It is clear from the illustration in "Abecedary" what exactly a crow embroiders: we can see a piece of fabric with embroidery and sleeve shirt in the chest.

Another point we want to draw attention to is the aggressiveness of the pages of "Live Abecedary" by "FastAR Kids". After all, in edition prepublishing, one needs to consider what the abecedary teaches, which traits brings up. For example, in the verse the shark scares small fish, the peacock shows off to the cockerel, the frog, based on the context, jealous of the crane.

On the one hand, these verses reflect the nature of the corresponding creatures, but it is worth to choose those who can teach something good. Consequently, it is necessary to consider not only the presence of the corresponding letter, but also to take into account the educational potential of the selected material.

9. Correspondence between written and depicted. New technologies are great, but "FastAR Kids" publishing house, which prepared "Live Abecedary" with the augmented reality technology, should pay more attention to work with text and images before its animation. On the page dedicated to the $Ж$ letter, there is a "жаба" (frog) word, which is mentioned in the text, but there is no stork, no crane, no conferva to get bogged down in it. At the same time, we must admit the brightness of the design, clearly visible letter.

\section{CONCLUSIONS}

At one time, the children's writer Vsevolod Nestaiko in an interview with the "Day" newspaper rightly emphasized: "Don't our authorities understand that the independence of Ukraine, oddly enough, depends on Ukrainian children's literature. If children do not read books in Ukrainian, they will not know their mother language, they will not become Ukrainians, and they will not give a hoot about independence" 25 . An abecedary is one of the first books of a child. It is traditionally produced in a book format with illustrative and text elements, but other variants of production are possible: in the form of cards, interactive posters, jigsaw puzzles, toy blocks, magnets, etc. One of the latest things

${ }^{24}$ Фіранка. Словник української мови: в 11 т. Київ, 1979. URL: http://sum.in.ua/s/firanka (дата звернення: 27.05.2018).

${ }^{25}$ Нестайко В. Незалежність України залежить від української дитячої літератури. День. 2003. 29 січ. № 16 (1517). С. 6. 
on the publishing market are publications, created with the help of ARtechnologies, or technologies of augmented reality.

Analysis of the abecedaries from the Ukrainian publishing houses, such as "A-ba-ba-ha-la-ma-ha", "Ailes", "Veselka", "Old Lion Publishing House", "Publisher FO-P Zalohin S. O.", "Krystal-Buk", "Mamino", "Mango", "Pehas", "Pero", "Ranok", "Talant", "School", "Yunisoft", "Vivat" shows that in prepublication it is necessary to consider the following: correspondence to the declared genre (abecedary); correspondence of the issue title to the content; representation of all letters in the alphabet; careful selection of lexical material; correspondence to the norms of modern Ukrainian literary language; emphasis marking in words; highlighting of the corresponding letter in a different color; careful selection of illustrative material considering educational potential and national traditions; correspondence between written and depicted.

In general, we must note that the production of the abecedary requires constant attention of specialists from various fields: educators, philologists, psychologists, designers, publishers, IT specialists, etc. Only their fruitful cooperation makes possible to manufacture a product that will promote the development of a harmonious, nationally conscious personality that respects the achievements of world culture, recorded in the books, and, accordingly, the further progress of the state as a whole.

\section{SUMMARY}

The section analyzes the variants of the Ukrainian abecedary. It is one of the first books of a child. Abecedary is traditionally produced in a book format with illustrative and textual parts, but other variants of production are also possible: in the form of cards, interactive posters, toy blocks, jigsaw puzzles, stencils, coloring books, mobile games, etc. One the latest things on the publishing market are publications, created with the help of AR-technologies, or technologies of augmented reality. The prepublication of the abecedary requires constant attention of specialists from various fields: educators, philologists, psychologists, designers, publishers, IT specialists, etc. Only their fruitful cooperation makes possible to manufacture a product that will promote the development of a harmonious, nationally conscious personality that respects the achievements of world culture, recorded in the books, and, accordingly, the further progress of the state as a whole. 


\section{REFERENCES}

1. 4 книжки-кубика. Моя первая азбука в стихах. URL: https://www.clever-media.ru/CleverProducts/ Books/book_16662/ (дата обращения: 30.04.2018).

2. Абетка. Словник украӥнської мови: в 11 т. Київ, 1970. URL: http://sum.in.ua/s/abetka (дата звернення: 27.05.2018).

3. Абетка Барвистих Вигуків. MAMINO: сайт. URL: http://maminobooks.com.ua/detskie-knigi/Abetka-Barvystyh-Vygukiv (дата звернення: 27.05.2018).

4. Весела абетка. URL: http://abetka.ukrlife.org/abetki.html (дата звернення: 07.05.2018).

5. Видавництво «Школа». URL: https://schoolbook.com.ua/ru/ books/abetka-chitayka/ (дата звернення: 30.04.2018).

6. ДСТУ 3017:2015. Інформація та документація. видання. Основні види. Терміни та визначення понять. Київ: Держстандарт України, 2016. 38 с.

7. Жива абетка. URL: https://www.yakaboo.ua/zhiva-abetka1641098.html (дата звернення: 30.04.2018).

8. Зубрицька Н. У Львові створили першу українську інтерактивну абетку. URL: https://zaxid.net/u_lvovi_stvorili_pershu_ ukrayinsku_interaktivnu_abetku_n1263554 (дата звернення: 28.04.2018).

9. Інтерактивні абетки, плакати. URL: https://toys.com.ua/ ua/govoryaschie-azbuki (дата звернення: 30.04.2018).

10. Мишеняткова абетка. Дитяча інтерактивна гра. URL: http://www.mousealphabet.com/ua/ (дата звернення: 30.04.2018).

11. Нестайко В. Незалежність України залежить від української дитячої літератури. День. 2003. 29 січ. № 16 (1517). С. 6.

12. Нил Гейман: Почему наше будущее зависит от библиотек, чтения и мечтаний. URL: http:/www.kobu.kiev.ua (дата обращения: 27.04.2018).

13. Пазл. Вікіпедія. URL: https://uk.wikipedia.org/wiki/Пазл (дата звернення: 30.04.2018).

14. Редакторская подготовка изданий: учебник / под общ. ред. С. Г. Антоновой. Москва: Изд-во МГУП, 2002. 468 с.

15. Словник української мови: в 11 т. Київ, 1979. URL: http://sum.in.ua/s/fotelj (дата звернення: 30.04.2018). 
16. Фіранка. Словник української мови: в 11 т. Київ, 1979. URL: http://sum.in.ua/s/firanka (дата звернення: 27.05.2018).

17. Фотелі. Словник української мови: в 11 т. Київ, 1979. URL: http:/sum.in.ua/s/fotelj (дата звернення: 27.05.2018).

18. Bocmal. 25 найзнаковіших дитячих книжок незалежної України. URL: https://bokmal.com.ua/ books/25-dytiachykh-knyzhoknezalezhnoji-ukrajiny/ (дата звернення: 13.05.2018).

19. Devar: официальный сайт. URL: http://devar.ru/o_kompanii (дата обращения: 30.03.2018).

\section{Information about the author: Bessarab A. O.}

Doctor of Science in Social Communications, Docent, Professor of Journalism and Ukrainian Philology Chair, Classical Private University 70b, Zhukovskoho str., Zaporizhzhia, 69002, Ukraine 